\title{
Rethinking Security in the Age of Uncertain Globalisation: NEPAI and Human Security in Africa in the Twenty-First Century'
}

Charles Ukeje* $^{*}$

\begin{abstract}
Globalisation can hardly be said to have caused Africa's contemporary predicaments. However, it is clear that it continues to exacerbate them by posing diverse challenges to local and global governance and security. This paper demonstrates how the New Partnership for Africa's Development (NEPAD), launched in 2003 to promote security and development, may be another hoax in Africa's search for appropriate development models, especially given the character and fall-outs of globalisation on the continent. It raises several critical questions regarding the relevance and practicality of the vision and mandate of NEPAD vis-à-vis Africa's innumerable security challenges. What, for instance, are the 'new' security challenges facing Africa in this age of globalisation, and how well equipped is NEPAD to addressing them? What are the key human security issues in Africa's developmental complexities, distinct from or similar to existent ones on regime and/or territorial security? What are the implications of globalisation in Africa's capacity to implement NEPAD's visions and priorities in the areas of security and development? In conclusion, the paper reveals that there is little hope that NEPAD would serve Africa's security needs better, whether it is now or in the future.
\end{abstract}

\section{Resumé}

Il n'est guère possible de dire que la mondialisation est la cause des situations difficiles qui prévalent en ce moment en Afrique, mais elle continue

* Political Science and Public Administration Department, the University of Buea, Cameroon. 
sans nul doute à les exacerber en posant de multiples défis liés à la gouvernance ainsi qu'à la sécurité nationale et mondiale. Cet ouvrage montre comment le Nouveau Partenariat pour le Développement de l'Afrique (NEPAD), qui a été lancé en 2003 pour promouvoir la sécurité et le développement, pourrait être un canular de plus pour l'Afrique dans sa quête de modèles de développement appropriés. Particulièrement si l'on tient en compte le caractère et les répercussions de la mondialisation sur le continent. Ceci amène à poser plusieurs questions cruciales sur la pertinence et l'aspect pratique des visions et missions du NEPAD à relever les innombrables défis sécuritaires de l'Afrique. On pourrait se poser les questions ci-après: Quelles sont les 'nouveaux' défis liés à la sécurité auxquels l'Afrique pourrait être confrontée à l'ère de la mondialisation et est-ce que le NEPAD est bien outillé pour les relever? Quelles sont les questions clés de la sécurité humaine relatives aux complexités du développement de l'Afrique, différentes de ou identiques à celles existantes et qui sont liées à la sécurité des régimes en place et/ou des territoires? Quel est l'impact de la mondialisation sur la capacité de l'Afrique à mettre en oeuvre les visions et priorités du NEPAD en matière de sécurité et développement? Pour finir, l'ouvrage révèle qu'il y a très peu d'espoir que le NEPAD aide à mieux satisfaire les besoins, que ce soit les besoins actuels ou futurs de l'Afrique en matière de sécurité.

\section{Introduction}

Africa has consistently evoked the image of a 'deeply troubled' continent on an inescapable path towards self-obliteration (Richards 2003; Bracking and Harrison 2003; French 2004; Gberie 2005: 337-342). At a time when other regions of the world are counting their achievements no matter how miniscule, Africa is backtracking on virtually all human development indicators. Its peoples are known to be far poorer today, living on a daily income level below one dollar, than in the 1960s when many of them gained independence. The continent's share of global trade is pegged around two per cent, contributing even less (about one per cent) to total global economic output. ${ }^{2}$ Apart from the tiny fraction of the national elites in different African countries that have helped themselves to stupendous riches deriving from endemic corruption, while the majority of the people live in chronic poverty. Africa reveals a worrisome nexus between poverty and conflict (Fayemi and Hendickson 2002: 67) as the continent is also the worst hit by unprecedented social carnage and civil wars (Jackson 2000; Bassey 2003; Boulden 2003; Abdullah 2004; Akindes 2004; Alusala 2004; Bischoff 2005; Jaye 2005; Richards 2005) 
forcing almost twenty per cent of its total population, or over 150 million people, to be trapped in conflict zones according to the African Development Bank (Ilorah 2004: 226).

Five decades down the post-independence road, the momentum of development that was enthusiastically pushed during the first decade of independence has dissipated, now replaced by appalling socio-economic, environmental and political conditions. But then, side-by-side with these disturbing nightmares are modest advancements, most notably recorded in the political sphere with the conduct of multiparty elections in about forty-two countries across the continent. In retrospect - and despite the limitations inherent in Africa's political transitions - the sheer number of countries that have made the difficult transition from full-blown military/civilian authoritarian regimes to various shades of multiparty civilian have rekindled hope that the continent can still be redeemed. Such complexities of, and contradictions in, Africa's recent socioeconomic and political experiences prompted the editorial in the Commonwealth Journal, The Round Table, to inquire whether the socalled giant strides in Africa are 'merely straws in the wind' or 'rearguard actions in a war the continent ... is losing, a war against poverty, disease, misgovernment and consequent military carnage' (Field 2004; Cooper and Pugh 2002; Jaye 2003; Clover and Cornwell 2004; Taiser and Matthews, 2004; NEPAD 2005). ${ }^{3}$

In part, the continent's myriad woes have been blamed more on the post-colonial miscarriage of governance than the complicity of external forces. In those diagnoses privileged by multilateral donors and financial institutions, for example, Africa's consistent poor performance is linked closely to 'insufficient investment aggravated by poor management' (Ilorah 2004: 226). When occasionally the role of external actors is acknowledged, their various dimensions and far-reaching impacts are only partially flagged. Writing on Africa's place in world politics, for instance, Taylor and Williams insisted that the discourse of the continent's marginality 'is a nonsense' since 'the continent has in fact been dialectically linked, both shaping and being shaped by international processes and structures' (2004: 1). Paul Nugent reportedly warned that such patronising and glossy conclusions about Africa have become most 'unreflective' as they hardly place the material conditions of the continent in any kind of historical context (Cited in Gberie 2005: 338). As Ihonvbere (2000) noted earlier, by brushing aside the historical footage to Africa's contemporary developmental failures, 'the victims of current 
predicaments and conditions are blamed or represented as hapless and willing actors in the process of reproducing underdevelopment and dependence'.

This paper takes its point of departure from the concern that it would be far more catastrophic to give up on the ongoing search for viable developmental alternatives and trajectories for Africa in the twenty-first century. A further point is that the continent's failure to improve the welfare and living conditions of its peoples is not so much because efforts have not been made in the past. Since the 1960s, several creative blueprints for development have been implemented, although unfortunately, they have not yielded good results because they were designed and implemented based on misguided and fallacious grounds (Diescho 2002: 8-9; Ilorah 2004: 235-238; Mbaku 2004: 391-392). Here, the crucial reference is the New Partnership for Africa's Development (NEPAD) launched in 2003 to promote security and development throughout the continent. Although a relatively infant initiative, NEPAD has received a lot of attention, most especially outside Africa.

The idea behind NEPAD must be understood against the imperatives and challenges of globalisation which is now celebrated as the new magical wand for equitable global development. What is more evident for Africa however are the flipsides of globalisation: rising unemployment, social dislocation, collapse of productive sectors, etc., all undermining and destroying the capacity of many developing countries to efficiently manage their affairs. Globalisation is also deepening, in multiple fundamental ways, the scissors dilemma of security and development that it is no longer feasible to retain the dominant narratives of 'security' focusing principally on regime and territorial security without taking cognisance of human security imperatives. This paper demonstrates how NEPAD, framed in the context of globalisation, may be another hoax in Africa's search for appropriate developmental paradigms. In short, given the character and fall-outs of globalisation on the continent, there is little hope that the conception and implementation of NEPAD would serve Africa's security better in the future. The paper raises several critical issues relating to the relevance and practicality of the visions and mandates of NEPAD vis-à-vis the management of Africa's myriad conflict and security challenges. What are these 'new' security challenges in this age of globalisation, and how institutionally equipped is NEPAD towards addressing them? What are the substantive human security issues in Africa's security and developmental equation, and how are they distinct 
from or similar to those focusing on regime and/or territorial security? How is globalisation implicating, good or bad, Africa's capacity to implement the visions and priorities of NEPAD with regards to security and development? The rest of the paper is devoted to: (i) Globalisation and its Uncertainties: Shifting Paradigms in African Security; (ii) the Changing Discourse on Security: From State to Human Security; (iii) NEPAD and the Fictionalisation of Human Security in Africa; and finally (iv) Alternative Futures and Challenges of Human Security in Africa.

\section{Globalisation and its Uncertainties: Shiiting Paradigms in Airican Security}

The various facets and impacts of globalisation, especially regarding Africa, cannot be contemplated in this short reflection. A good point of departure would however be to bear in mind that the current globalisation did not cause Africa's contemporary predicaments even though it continues to exacerbate them. The logic driving Africa's developmental problems can be traced to a variety of external and internal factors, beginning from the manner and processes through which the continent was absorbed, forcefully, into global capitalism from the mid-1500s. Some of the highlights of the African experience during that long colonial moment have been identified by Ihonvbere (2003: 3-4) as including the experience of slavery; the termination of endogenously driven patterns of state and class formation; the imposition of colonial rule; the balkanisation of the continent and the imposition of alien values, tastes, and institutions; the creation of a repressive corrupt, unproductive, unstable, and illegitimate state; the creation of a highly fractionalised, factionalised, dependent, corrupt, and weak elite; the domination of the African economy by profit-and-hegemony-seeking transnational corporations dedicated to making profit at all cost; the total denigration of local cultures, values, and institutions, and the introduction and promotion of primordial differences and suspicions; and finally, the structured incorporation of the African economy into the periphery of the global division of labour and power as vulnerable, dependent, underdeveloped, weak, and largely raw material-producing region. In virtually all postcolonial African countries, there remain vestiges of colonial rule, most notably those manifesting themselves in the contradictory manner in which state-society relationships evolved and are maintained (Fawole 2004: 297-303).

Although there is substantial intellectual interest in and fascination with the circumstances and conditions that have kept the post-colonial 
state in Africa alive, it is partly by interrogating it in all its ramifications that contemporary African security problems and challenges can be unravelled. Arising from this, the first point is that the post-colonial state has survived on the continent because it has held on precariously to the 'authoritarian and social licenses' to govern by creatively adapting itself, hardly altering or compromising the raw power at its disposal (Ihonvbere 2000). Second, with the character of its composition, the political elites in charge in different post-colonial African states paid more attention to their own survival than to the welfare and security of their people. By the 1990s, insecurity became accentuated due to the growing inability of the political class to continue to mobilise domestic support and external patronage. This period provided the backdrop for many of the violent conflicts and civil wars in Africa, most of which have roots in a complexity of colonial and post-colonial social, leadership, resource, personality, class, ideological, ethnic, territorial, and religious divisions (Herbst and Mills 2003: 7; Bassey 2003: 43).

How globalisation is affecting Africa generally has become a topical subject in the social sciences over the last decade (Cooper 2002; Hughes 2002; Juhasz 2002; Meagher 2003; Morton 2004; Swyngedouw 2004). By way of caveat, there is a need to acknowledge that different historical moments experienced globalisation in different ways. What may be unique about the current one can be explained in terms of its scope (global spread), intrusivity (the degree of penetration) and intensiveness (the resultant changing effects). Specifically for Africa, the delivery and impacts of these various globalisations have remained essentially the same. As colonialism, it represented political and administrative domination mainly to facilitate extraction and accumulation. After independence, globalisation manifested itself as imperialism by helping to deepen accumulation even further, allowing the persistence of human indenture, magnifying the inequality of capitalist expansion and generally provoking violent disorders (Bracking and Harrison 2003: 6-7). During the 1980s, globalisation was represented by the activities of the IMF/ World Bank under the neo-liberal Structural Adjustment Programme (SAP).

Today, globalisation is leading to the contraction in time and space, the ease of capital mobility and radical transformations in the organisation of human affairs and social life (Bischoff 2005: 7-1 1; Held 1997: 251267). In most African countries, each phase of globalisation has helped to nurture and reinforce the other, especially by accelerating the decline or collapse of welfare and social security safety nets. Thus while those 
who celebrate globalisation highlight the phenomenal increase in the movement of peoples, coupled with unprecedented flows of goods, services and capital around the world (Ajayi 2004), those critical of it insist that the agency of globalisation is too destructive as it widens social disconnections and social dislocations leading to frequent and intense violent conflicts (Held 1997: 257-8). While it provokes a 'return to familiar conditions of subordination' (Clapham 1996: 24), the Ugandan political analyst, Catherine Odora Hoppers, described the current phase of globalisation and the neo-liberal ideology driving it as simply a "continuation of the war that began with colonialism and never ended' (Hoppers 25, 2, 2000: 149). What globalisation is doing to Africa in particular, and to most developing countries of the South, is intensifying

age-old group antagonisms: sublime racial politics, regional economic disparities, and worsening global poverty ... It disguises the true nature of the North-South divide and generates the illusion that to transcend differences is to overcome it. Globalisation does not and cannot foster equity because its technology is driven by the same exploitative trade regimes which it supposedly called out of order (Obono 2004: 90-91).

In 'Globalisation, Equity and Development: Some Reflections on the African Experience', Olukoshi (2004: 32-42) recognised the legitimate worry deriving from globalisation as he showed how the world is seeing the worst and most extensive process of social exclusion ever known, occurring side-by-side with the 'single-minded, ideologically-motivated retrenchment [and de-energising] of the state and the erosion of its capacity' $(2004: 24,27)$. Thus, at the same time that developed countries are putting in place robust policies to cushion the side effects and threats from globalisation, they are dissuading, even coercing, their weaker counterparts in the South from pursuing their own independent interests on the pretext that the state must roll back its presence and allow the market to mobilise and allocate social capital. Since 'decay seems to outweigh renewal', therefore, Olukoshi warned that the biggest challenge facing Africa consists of 'renewing and retooling the State in order to enable it to resume a meaningful role in the developmental process' (2004: 39). Obviously, this is where the irony about globalisation and African security problematic most reveals itself: at the same time that globalisation is undermining the capacity of the state, the state itself is still expected to play a major role in the stability and security of the continent. 
Unfortunately, the twenty-first century has ushered in a profound sense of anxiety that security and development could escape Africa (Chandler 2004). Going by today's benchmark as contained in the UN Millennium Development Goal (MDG) targeting the reduction of poverty by half, scaling-up access to safe drinking water and achieving universal basic schooling by 2015, there are indications that Africa may not even be on track yet (ARB 2003: 15099-15134; Mepham and Lorge 2005). While such concerns have placed Africa on the top of the agenda of the international community, especially the G8 countries, a consistent pattern of deception seems to pervade the policies and actions of these countries as they refuse to acknowledge or even discuss the root causes of Africa's underdevelopment located in their low capacity and limited access to global resources and opportunities. One example that readily comes to mind in this respect is the on-going African Growth and Opportunity Act (AGOA) pursued by the United States. According to Carol Thompson (2004) AGOA is providing neither growth nor opportunity for African economies, not just because only six African countries have benefited from the initiative, but also that it offers much less in terms of 'shared values' and 'shared responsibilities'. She demonstrated how western insincerity is leaving Africa in the doldrums while the rich countries spent $\$ 300$ billion in 2003 alone on farm subsidies; almost six times more than on development aid (2004: 472). Mepham and Lorge (2005) advised the G8 countries to put their houses in order by stopping harmful practices creating gaps in western rhetoric and actions towards Africa, especially with respect to the nature of aid and conditionality, discriminatory international trade regimes, the fuelling and exacerbation of armed conflicts and the strengthening of repressive regime by supplying them with arms and military equipment, financing corruption and conflicts, and their contribution to adverse climate change (Olsen 1998, 2002, 2004).

Until now, the wealthiest countries of the world have feigned ignorance of the perilous consequences and wider repercussions of the accentuation of Africa's catastrophic developmental problems. This explains, in part, why the response by Western countries is now distinguished by 'a continual schizophrenia' on whether policy towards Africa should be based on a set of 'goods', that is, increased investment, aid, a liberalised trade regime, or on a set of 'bads' (Herbst and Mills 2003: $31)$ such as the HIV/AIDS scourge, war, crime and refugee flows, the spread of disease, trafficking of persons, arms and illicit drugs, and glo- 
bal terrorism (Farah 2002; Abrahamsen 204b; Addo 2004; Botha 2004; Keenan 2004; Lyman and Morrison 2004; Mentan 2004; Mills 2004; Mepham and Lorge,2005: 9). Encouraged by convergence in the development and security policies (Willet 2004: 101) the set of 'bads' seem to be gaining ascendancy after 9/1 I leading to a shift from development/ humanitarianism to a category of risk/fear/threat. Securitisation is, in turn, driving policies of containment, or policing, and promoting a strange version of trusteeship-style responsibility to 'quarantine disorder'. The securitisation of development is strongly demonstrated through the United States-led global anti-terrorism movement. From a different perspective, however, this global effort may in fact further undermine human security in Africa as the discourse of anti-terrorism is used to intimidate opponents of government in different countries (Farah 2002; Keenan 2004; Lyman and Morrison 2004). It is also not a coincidence from the way it is pursued, that the war on terror is becoming synonymous with poverty alleviation, making them two sides of the same policy coin. Furthermore, the securitisation of Africa is becoming another political strategy for rallying and unifying domestic constituencies behind government at a time of vociferous anti-government oppositions, and by so doing, to produce a sense of prioritisation and urgency not necessarily to justify increased development assistance but other political exegeses (Abrahamsen 2004: 680-682; Deegan 2004; Cawthra 2004: 27-28).

What is undeniable from the analysis above is that globalisation is posing new challenges to local and global governance, especially as it affects the management of global public goods: health, education, employment, human security, to mention a few (Federici 2000; Graham and Poku 2000; Cooper 2001; Juhasz 2002; Lawson 2003; Meagher 2003; Forge 2004; Morton 2004; Federici and Caffentzis 2004). Adebayo Adekanye drew attention to those human and social aspects of globalisation that have been thrust onto the global security (and research) agenda, including:

... rising poverty and rising incidents of conflict, rising migration and refugee flows, increasing environmental stresses and strains, demographic pressures on resources, deterioration in human security provisions, the diffusion of military technological know-how, skills and expertise of sub-state actors, proliferation of illegal arms, drug trafficking, money laundering, and international terrorism - all of which have combined to constitute the new security issues and concerns of contemporary times (2004: vi). 
At the same time, new models of governance and security are required which rescue the state in Africa from its current precarious situation. This nexus between governance and security is a core question examined in Claude Ake's The Feasibility of Democracy in Africa. As he rightly noted, threats to democracy in Africa are the same ones accelerating the process of social decay and political instability, and undermining peace and security in the continent. The most deadly threat of all comes from how the process of globalisation is changing 'traditional assumptions to the effect that the nation-state is the inevitable basic political organisation of humankind' while 'undermining the nation-state and its relevance, leaving its future in doubt'. As the 'repository of sovereignty', 'the nationstate is now forced to contest power with sub-state and super-state political formations that have neither a root nor legitimacy'. He further showed how globalisation is causing the 'annulment of the social' by privileging the market over the state (Ake 2000: 26-28). By allowing the market to play a much greater role over and above the state, and removing the conditions that 'make the public possible', globalisation is undermining the state as the most important organisation of power on the continent (Nnoli 2003: 23-25). Indeed, it is difficult to contemplate an alternative framework to the State, certainly not the imperfect and anonymous market. Perhaps, then, the search for creative ways to make the state more relevant to the yearnings and aspirations of the people should be the most urgent priority of our time (Vasu 2005). At the same time, there should be a complementary reinvigoration of the civil society in terms of demanding its rights and serving as watchdog against the excesses of the state. Thus, re-energising the state and civil society are two sides of the same coin as they open up the issue of how the state should treat the people and what concurrent obligations the people have towards the state. This is an issue that will be explored further in the context of an assessment of the viability of NEPAD to respond to human security challenges and problems in contemporary Africa. Whereas globalisation has transformed the security landscape in Africa, old ways of managing security have been slower and less innovative in following suit (Bush and Keyman 1997). This much is clear from the paucity of any credible response to the resurgence of provocative identity-related conflicts on the continent, particularly from the 1990s onward. This is the template for the call to abandon, or at the very least, expand existing parameters of security beyond the present focus on state/regime/territorial 
security to include specific human security priorities and concerns (Pettman 2005: 137-150).

\section{The Changing Discourse on Security in Airica: From State to Human Security}

Inadvertently, globalisation has opened a wider epistemological and policy window for rethinking and responding to Africa's myriad security problems and challenges in the twenty-first century. At the epicentre of these farreaching changes is that traditional boundaries between state and civil society, and among different states, are breaking down or transforming in far less predictable ways. Dominant conceptions of security can no longer hold given the complexities of unfolding global relations. With new security threats emanating from non-traditional military sources: population growth, environmental degradation, resource scarcity, drug trafficking, transnational criminality, the violation of cultural and indigenous rights, there is no better time to commence sober and critical reflections on the shape, form and content that security discourses and practices are going to assume in Africa over the next decades (Vayrynen 1995: 259-260). This is against the background that the continent has become a major flashpoint of bloody civil wars and protracted lowintensity conflicts since the Cold War safety valves provided by the United States and the Soviet Union are no longer in place. These new conflicts are occurring within states with their "primary locale ... found where there is a combination of entrenched poverty, an excessive dependence on natural resource exports, and poor economic governance and state weakness' (Clover 2004: 8-9). It is very difficult to distinguish new types of conflicts as they are all characterised by criminal impunity, wanton violation of human rights, humanitarian emergencies such as massive internal displacements and refugee flows, collapse of livelihood sources and municipal facilities, the spread of communicable and life-threatening diseases, the proliferation and widespread use of small arms and light weapons, to mention a few. They are largely driven by a variety of militaristic ideologies that incubate a frightful regime of terror and insecurity over time (Boyd 2005: 1 17; Abdullah 2004). Almost a decade ago, one study indicated that 'armed conflict is surely one reason why at least 250 million people in Sub-Saharan Africa- nearly half of the population- are living below the poverty lines' (Colletta, Kostner and Wiederhofer, 1996: ix). There is a legitimate fear that identity and resource-induced conflicts could undermine whatever modest progress has been achieved on the continent at this moment when national security 
infrastructures are so weak as to allow renegade groups to thrive. These new African wars are assuming a pattern of viciousness, impunity, plunder and profiteering.

Since there is 'considerable ambiguity and confusion about just what kind of security system' is most appropriate for Africa, Ajulu (2004: 265-282) argued that a desirable framework for security in Africa must dwell more on human security, that is, the welfare of the individual, and by extension, the community, as against threats to regimes and the territoriality of nation states. After attention was drawn to 'human security' by the UNDP in its Human Development Report of 1994, this concept is regaining global salience with emphases on the core values of human freedom and human fulfilment. UN Secretary General, Kofi Annan distinguished between what he called 'territorial sovereignty' and 'individual sovereignty', the latter defined in terms of the 'fundamental freedom of each individual ... enhanced by a renewed and spreading consciousness of individual rights ... not to protect those who abuse them' (Cited in Oberleitner 2005: 194). According to the co-chairs of the Human Security Report, Sadako Ogata and Amartya Sen, human security means "protecting vital freedoms - fundamental to human existence and development. It pays particular attention to protecting people from severe and pervasive threats, both natural and societal, and empowering individuals and communities to develop the capabilities of making informed choices and acting on their own behalf' ${ }^{4}$ (Cited in Oberleitner 2005: 187). Human security is therefore about

safety for people from both violent and non-violent threats. It is a condition or state of being characterised by freedom from pervasive threats to people's right, their safety or even their lives ... It is an alternative way of seeing the world, taking people as its point of reference, rather than focussing exclusively on security of territory or government. Like other security concepts - national security, economic security, and food security - it is about protection. Human security entails preventive measures to reduce vulnerability and minimize risk, and taking remedial action when prevention fails (Sabelo 2004: 299; cf. David Hubert 1999).

Boyd (2005: 1 15) defined human security as 'the ability to pursue those choices in safe environments broadly encompassing seven dimensions of security - economic, food, health, environmental, personal, community, and political'. Kanbur (2002: 93) conceptualised human security in terms of vulnerability and voicelessness associated with poverty in the face of 
unresponsive local and national institutions. Without real peace, as Boyd (2005: 1 16) pointed out, there are no prospects for development or equality. Real peace, quoting Ursula Franklin, is understood to mean

... more than the absence of war. It is also the absence of fear; fear of the knock on the door in the middle of the night, fear of hunger and helplessness, fear of the absence of justice. Peace is, then, the presence of justice for all, peace means respect for all human needs as well as the condition that force, in all its forms, is not an instrument of national or international policy (Boyd 2005: 119).

Peace, generally understood in terms of ending widespread and continuing violence, is limited by its emphasis on physical violence, involving bodily harm or the destruction of properties, without cognisance of structural violence, involving less visible constraints on human potential due to economic and political structures (Galtung 1969: 167-191). Based on conventional wisdom, issues having to do with broad-based recovery (involving improvements in the incomes and human development indicators of the majority of people) hardly feature in the discourse of violence and insecurity. By implication, this narrow and short-term security concern usually paves the way for shoddy and half-hearted interventions that leave too many issues unresolved. In countries where prolonged atrocities have been committed against the civilian population, for instance, human security concerns are barely pursued after peace processes have been consummated and a new government sworn in (ARB, March 2004: 15663-15698). In such countries, international humanitarian efforts mobilised during civil wars quickly dissipate, leaving them distressed and at risk. This concern for the long-term needs of post-war countries prompted the proposal by the International Crisis Group in its report on Liberia and Sierra Leone that longer periods, between 15-25 years, of sustained international support for post-war countries was necessary if they were not to slide back into bloody civil wars (Manning 2002). It is also in this context that Addison (2003: 3-5) proposed that the emphasis should go beyond rebuilding shattered or collapsed infrastructure to investing in 'social capital, including the trust that creates informal safety nets' and by so doing, altering the behaviour of critical national actors (Harris 2004: 5-10).

The quest to appropriately redirect security towards human-centred concerns raise several problems. First, human security is still a heavily contested concept in terms of definition, scope and utility. Thus, there is still a lot of suspicion and criticism over the tendency to overstretch the 
traditional notion and boundaries of security; much the same way that 'environmental security' entered the security lexicon almost a decade ago. A second critique is that human security is far too universalistic, thus raising false priorities and hopes around the securitisation of human beings. By maintaining existing boundaries, orthodoxy restricts 'security' to the political survivability of states and regimes to the exclusion of equally important economic, environmental, cultural and non-political threats. Also, by placing the state at the epicentre of the design of security architectures, existing paradigms suggest that non-political threats 'become integral components of our definition of security only if they become acute enough to acquire political dimensions and threaten state boundaries, state institutions, and regime survival' (Vayrynen 1995: 260). Not least is the limitation that human security cannot be fully achieved for as long as the quest for peace and security are linked with the authoritarian values and motivations of political leaders who exercise power with impunity (Sabelo 2004: 306; van Niekerk 2004). Adele Jinadu (2000) offered further perspectives on how human security suffers when custodians of the state seek to retain and extract compliance through the instrumentality of coercion. He explained how the problematic of peace and security is intrinsically bound up with human nature, especially the dialectics of the social psychology of human interactions, under conditions of scarcity and choice'. Accordingly, the problem of peace and security 'cannot and should not be divorced from the dialectics of domination and subjection, in other words from considerations of superordinate/subordinate relations at the community, national and global levels' (Jinadu 2000: 1-3). The crucial question, as he pointed out, is '[If] humankind cannot create a perfect society, given human nature and the reality of scarcity, as well as the difficult and contentious questions of choice which scarcity poses, what needs to be done to create a less imperfect society? Under what conditions can such a less imperfect society be expected to emerge and thrive?'

Against the background of the complex welfare and safety problems experienced in Africa, improving human security as a condition of existence which has both quantitative and qualitative aspects, has farreaching policy implications for the contrived post-colonial state (Thomas and Wilkin 1999). Indeed, human security calls into question which type of state is more able to enhance human security, and whether, in fact, states themselves are a potential solution to human insecurity or a major part of the problem. In the circumstances that the post-colonial 
state in Africa is itself struggling to perform its most basic functions, there is no guarantee that the human security needs of the vast majority of the citizens can be met, not to talk of being satisfied. Even if one accepts that the post-colonial state as presently composed in Africa is not in a position to 'monopolise the concept and practice of security' (Oberleitner 2005), the follow-up question to ask is where then should the state acceptably belong in the process of reconstructing the security landscape to bring in and accommodate human security? Ironically, the immediate wisdom is to accept that the project of enhancing human security cannot possibly progress or be accomplished without the active participation of the state. Since the state cannot be excised, therefore a human security approach means both refocusing the state as well as providing within it a congenial environment that allows for the promotion and protection of the well-being and safety of the population as equally important goals (Graham and Poku 2000).

The above necessarily leads to another important issue: the impossibility of separating human and regime securities from the process of democracy building and consolidation, as well as development in Africa (Jinadu 2000: 4, 9). As a categorical imperative, peace and security provide a critical theoretical, moral, political and philosophical benchmark in the core assumptions of justice and equality that can be used to measure and approximate how societies are moving or drifting further away from the ideal (Ake 2000: 9). As the Cold War ushered in a renewed interest in governance issues and reforms, what seems wrong is how these governance issues are driven more from without than within, thus limiting critical imperatives such as the need for local content and a sense of inclusion and ownership (Cawthra 2004: 30-31). A shift in focus to human security would reverse this situation, pave the way for a better understanding of the major sources of threats to human security, and stimulate the quest for appropriate reformulation of strategies for addressing them. This was the framework within which Willet (2004: 114) suggested viewing state-society relations differently, especially because the capacities required to enhance human security in Africa are quite different from those that focus almost exclusively on the security of the state, regime or military security. The overall challenge is to cultivate and 'shape a security paradigm that captures the need to reach out in defence of people as well as the states' (Oberleitner 2005: 190191). 


\section{Another False Start? NEPAD and the Fictionalisation of Human Security in Airica}

How African states are able to grapple with and respond to pressing issues that impinge on the welfare and survival of its vast population will determine the present and future qualities of human, social and national security on the continent. The choice for countries of the South, according to President Thabo Mbeki of South Africa, 'is not whether to engage with globalisation or not but how to engage with it' (cf. Griggs 2003: 76). It is partly an attempt to answer the question of 'how' that the New Partnership for Africa's Development (NEPAD) was established in Lusaka, Zambia, in July 200 I. It is important to recapture, no matter how briefly, the historical context to this new initiative beginning from when the defunct Organisation of African Unity (OAU) was created in Addis Ababa, Ethiopia, in 1963. Since that time, several major issues and common concerns have occupied African countries. For example, to promote unity and solidarity among members of the Organisation; coordinate and intensify their cooperation and efforts to achieve a better life for the peoples of Africa; defend their sovereignty, territorial integrity and independence; eradicate all forms of colonialism from Africa; and promote international cooperation. In retrospect, it is a tribute to the OAU that by the time it was formally dissolved radical transformations had occurred within the African political landscape as evident in the complete termination of colonial rule and minority rule in apartheid South Africa. Although other problems persisted, or in some cases, multiplied (Packer and Rukare 2002: 37 I ff.), the enthusiasm for a new continental framework to give further impetus to Africa's developmental goals and aspirations was demonstrated by the speed with which the Constitutive Act of the African Union (CAAU) entered into force within two years. The AU mandate explicitly included issues relating to promoting and defending African common positions on issues of interest to its peoples; encouraging international cooperation; promoting peace, security and stability, as well as democratic principles and institutions, popular participation and good governance; promoting and protecting human and people's rights, establishing the necessary conditions which would enable the continent to play its rightful role in the global economy; promoting cooperation in all fields of human activity to raise the living standards of African peoples, and finally, working with relevant international partners in the eradication of preventable diseases and the promotion of good health on the continent (cf. Levitt 2003: 40-41, 55; 
Griggs 2003; Matthews 2001, 2003). Like its precursor, the African Union also adopted the principles of sovereign equality and interdependence, respect for borders, peaceful resolution of disputes, establishment of a common defence policy, non-interference, peaceful coexistence, and selfreliance, among others. The CAAU went further to identify other key principles such as the right of the Union to intervene in a Member State pursuant to a decision of the Assembly in respect of grave circumstances, namely: war crimes, genocide and crimes against humanity; the right of Member States to request intervention from the Union in order to restore peace and security; promotion of gender equality; respect for democratic principles, human rights, the rule of law and good governance; promotion of social justice to ensure balanced economic development; respect for the sanctity of human life, condemnation and rejection of impunity and political assassination, acts of terrorism and subversive activities; and finally, condemnation and rejection of unconstitutional changes of government (Levitt 2003: 41-42). These obviously are very significant additional mandates. But then, again, they have placed a huge question mark over the capacity, resources and even the political will at the disposal of the new organisation to achieve them (Tieku 2004; Forge 2004: 29). It is more in this regard that legitimate fears have been expressed that the same legal, procedural, fiscal and environmental constraints that hampered the OAU may also decapitate the new African Union.

Considering the grave implications for peace and stability in the continent, it is understandable that security concerns featured prominently in the enabling framework of the AU. It must be recalled that at the time the Constitutive Act was endorsed in 2000, the African continent was already choking from almost a dozen protracted internal conflicts and civil wars (Field 2004: 19). To give effect to these concerns, the Peace and Security Council (PSC) ${ }^{5}$ of the AU became the first initiative to be established, in July of that year, with a broad mandate to intervene in the affairs of states to preserve peace and the rule of law. The protocol establishing the PSC also made provided for a Panel of the Wise, a subregional early warning systems linked to a regional 'situation room' at the AU headquarters, the African Standby Force and a Peace Fund (Shannon 2004: 41-62; African Union 2005: 1). Apart from the PSC, the AU agreed to the idea of a Conference on Security, Stability, Development and Cooperation in Africa (CSSDA) proposed by Nigeria (Shannon 2004: 21-22) . 
The blueprint creating NEPAD derived its strength from the AU. ${ }^{7}$ NEPAD acknowledges good governance as a basic requirement for peace, security and sustainable political and socio-economic development; African ownership and leadership; and broad participation by all sections of the society. It anchored the development of Africa on its own resources and the resourcefulness of its people; on creating partnerships between and among African peoples; on accelerating regional and continental integration, building the competitiveness of African countries and the continent; on forging a new international partnership that changes the unequal relationship between Africa and the developed world; and finally, on ensuring that all partnerships with NEPAD are linked to the Millennium Development Goals and other agreed development goals and targets. African leaders that signed up to NEPAD resolved to 'eradicate poverty and to place our countries, individually and collectively, on a path of sustainable growth and development and, at the same time, to participate actively in the world economy and body politic on equal footing'. ${ }^{8}$ They acknowledged that poverty can only be effectively tackled through the promotion of democracy, good governance, peace and security; the development of human and physical resources, gender equity; openness to international trade and investment; allocation of appropriate funds to social sector; and new partnerships between government and the private sector, and with the civil society (par. 20, pp. 7-8).

To achieve its twin objectives of poverty eradication and economic development (par. 5, p. 3), NEPAD identified four areas of core emphasis: Democracy and Good Political Governance, Economic and Corporate Governance, Socio-Economic Development, and the African Peer Review Mechanism (par. 6, p. 3). Member countries also expressed their determination to increase ... efforts in restoring stability, peace and security in the African continent, as these are essential conditions for sustainable development, alongside democracy, good governance, human rights, social development, protection of environment and sound economic management'. They pledged to direct efforts and initiatives to 'move quickly towards finding peaceful solutions to current conflicts and to build Africa's capacity to prevent, manage and resolve all conflicts on the continent' (par. 9, p. 4). They accepted 'a binding obligation to ensure that women have every opportunity to contribute on terms of full equality to political and socio-economic development in all our countries' (par. 1 l, p. 4), while undertaking to 'do more to advance the cause of human rights ... to end the moral shame exemplified by the plight of women, 
children, the disabled and ethnic minorities in conflict situations in Africa' (par. 10, p. 4).

NEPAD prioritised eight codes and standards that should be observed by member countries 'within their capacity capabilities', i.e. 'minimum requirements, given a country's capacity to do so' (par. 17, p. 6). These priorities - with the potential to promote market efficiency, to control wasteful spending, to consolidate democracy, and to encourage private financial flows - include: a code of good practice on transparency in monetary and financial policies; code of good practice on fiscal transparency; best practices for budget transparency; guidelines for public debt management; principles of corporate governance; international accounting standards; international standards on auditing; and finally, core principles for effective banking supervision (par. 18, p. 6-7). Finally, NEPAD affirms the need 'to build on the promising foundation, working with our development partners and the wider international community to: forge new forms of international co-operation in which the benefits of globalisation are more evenly shared; create a stable international economic environment in which African countries can achieve growth through greater market access for their exports; the removal of trade barriers, especially non-tariff barriers and other forms of protectionism; increased flows of foreign direct investment; and debt cancellation'. NEPAD is touted, especially abroad, both as the most ambitious framework for 'moving the African continent from crisis to renewal in the past forty years' and as 'one last hope for Africa to reverse its slide into irrelevance' (Hope 2002: 397-389, 402; Diescho 2002).

Going by the letters and spirit of NEPAD, one can reasonably conclude that it covers most of the important aspirations of Africans (Mbaku 2004: 393). The framework acknowledges that peace, security, and democracy are important preconditions for economic development, including attracting much-needed foreign investment (Hope 2002: 392). This peace and security initiative is, in turn, based on three related elements: promoting long-term conditions for development and security; building the capacity of African institutions for early warning, as well as enhancing their capacity to prevent, manage and resolve conflicts; and institutionalising commitment to the core values of the New Partnership for Africa's Development through the leadership. To build Africa's capacity to manage all aspects of conflict, NEPAD focuses on strengthening existing regional and sub-regional institutions in four key areas: prevention, management and resolution of conflicts; peacemaking, 
peacekeeping and peace enforcement; post-conflict reconciliation, rehabilitation and reconstruction; and combating the illicit proliferation of small arms, light weapons and landmines.

These principles, objectives and action plans are bold and beautiful in print (Chabal 2002; Diescho 2002; Kanbur 2002; Melber, Cornwell, Gathaka and Wanjala 2002; Waal 2002; Hammerstad 2004; Herbst 2004; Matthews 2004; Malcomson 2004; Mbaku 2004; Adesina 2005). The temptation is to give NEPAD a chance to mature further before subjecting it to critical evaluation on the basis of its avowed objectives and achievements. But there are preliminary observations germane to its creation and existence so far that could serve as a useful guidepost for short-term and mid-term reviews. Olukoshi (2003: 21 -25) identified one major limitation of NEPAD as arising from its over-reliance on myths to sell itself to the public; myths that essentially represent a misreading of African past and recent experiences, but are gaining the status of truth with deliberate repetition. Four of such myths revolve around: (i) the idea that 40 years of independence in Africa has been characterised by a universal and uniformly dismal socio-economic record which NEPAD is now designed to correct; (ii) the claim that the initiative represents the first comprehensive programme to emerge from within Africa for resolving the developmental problems of the continent; (iii) the even more pretentious claim that it is the first truly African-owned framework for redressing the socio-economic and political difficulties of the continent; and (iv) the erroneous impression that NEPAD is the first truly marketfriendly initiative to have emanated from African leaders (see also, Herbst and Mills 2003).

Together, these myths have been developed to sell the neo-liberal logic on which the existence and legitimacy of NEPAD is dependent. This 'obsession with neo-liberalism and its willingness to integrate Africa into what is essentially an unjust global trade system' has been criticised on different occasions, including during the African Social Forum held in Bamako, Mali, in January 2002 (Mbaku 2004: 394). This pandering to the logic of a thoroughly discredited neo-liberalism that has failed Africa in the past is unfortunate. On the basis of its avowed commitments to neo-liberalism there is little hope that NEPAD would be able to mobilise sufficient autonomy and action to challenge or seek a comprehensive reform of the existing global political economy largely responsible for Africa's many predicaments. What seems to be happening is that the designers and operators of NEPAD are content with diligently falling in 
line rather than making any serious effort to amplify Africa's rights, for instance, to fair trade. At a time when consensus is building overwhelmingly within and outside that the global political economy has been unfair and unjust to Africa, it is curious that NEPAD is still calling for further integration through the instrumentality of trade liberalisation and the formation of free markets. Unfortunately, no matter which rosy form it is presented in, neo-liberalism can only accelerate and accentuate the deep-seated crises of development facing societies in Africa as it draws more and more people into poverty, rather than relieve them from it, as it promises (Mbaku 2004: 394). By leaning so heavily on neo-liberalism and market forces, NEPAD will be stalling if not subverting the expansion of welfare opportunities for the ordinary African as it creates room for profiteering (Matthews 2004: 503). It might also mean NEPAD is sacrificing the human rights of African peoples to the "whims of a volatile and untrustworthy global capital' (Mbaku 2004: 396). The worst scenario from the neo-liberal agenda of NEPAD, according to Mbaku (2004: 401), is that it is offering the West an opportunity to continue the exploitation of Africa which began almost five hundred years ago (Olsen 1998, 2002, 2004).

A closer look also reveals an even more sinister ambiguity in terms of the character and parameters of the proposed 'partnership' between NEPAD and the wealthier donor countries and institutions. Presently, NEPAD is claiming a development rhetoric which retains the political and economic governance processes elsewhere in the West as the model of what it means to be 'developed'. By pushing in this direction, the operators of NEPAD are not even thinking that there may well be other paths to development different from the one that the West is working hard to impose on Africa. Regardless of the claim to African ownership, NEPAD is still manipulated behind the scenes by its so-called development partners pushing for a strange type of partnership that further undermines the capacity of Africans to determine their own destiny and future (Matthews 2004: 497-500). It is this kind of partnership that is driving the Poverty Reduction Strategy Papers (PRSP) implemented since 1999 by the World Bank and the International Monetary Fund, after admitting that the celebrated Structural Adjustment Programmes of the 1980s turned out to be a disaster (Hope 2002: 400).

One of the most scathing criticisms of NEPAD is therefore that it is a 'western wolf in African sheepskin'. Rita Abrahamsen (2004a: 1454) suggested this label to underscore the initiative's subservience to western 
powers and values despite the rhetoric of ownership. According to her, 'partnerships are little more than conditionality by another name'; a form of advanced liberal rule 'that increasingly governs through the explicit commitment to self-government and agency of the recipient states'. It is also 'a form of advanced liberal power' working 'not primarily as direct domination and imposition, but through promises of incorporation and inclusion'. Recognising that their 'over-prescriptive and interventionist development models' have not worked satisfactorily, the West is retreating to the position that 'they are no longer in the business of telling poor countries what to do' (Abrahamsen 2004a: 1453-4). To appreciate the potency of the subtle form of power inherent in this partnership, Abrahamsen revisited the discourse on the logic of power relations but differently from the way it is usually understood as the capacity of certain actors to control directly the actions of others. She re-framed this new interpretation by adding a fourth aspect to the tripod of power proposed earlier by Lukes. According to Lukes, power manifests in three forms: (i) power employed by one actor over another; (ii) non-decision as a form of power characterised by the ability to shape political agendas and prevent issues from entering public debate; and (iii) the most insidious exercise of power involving the shaping of people's perceptions, cognitions and preferences in ways that may be contrary to their own interests but making them accept and work for the existing order of things, including their own domination.

The fourth dimension of power introduced by Abrahamsen incorporated 'governmentality as a form of power'. By governmentality, Abrahamsen was alluding to the 'the conduct of conduct', 'a particular modern form of power that is characterized by an increasing reliance on pastoral care and techniques of normalisation and consensus, as opposed to more overtly coercive forms of power' (2004a: 1458-1459). As political interventions designed to produce particular modern subjects, partnerships from the perspective of governmentality allows governments in weaker recipient countries the opportunity to learn to practice their freedom 'responsibly' in a way that capacity building is simultaneously empowering and disciplinary, in that both constitute and regulate the identities, behaviour, and choices of their target countries' (Abrahamsen 2004a: 1462). Accordingly, this type of partnership is not simply a trick of deception, or a rhetorical device, but has very real productive power which makes partnerships to function as 'a form of advanced liberal governmentality that increasingly governs through the explicit 
commitment to self-government and agency of African states' without necessarily losing the traditional notion of power as domination (Abrahamsen 2004a: 1463).

The allusion to partnerships is manifested concretely through contemporary donor practices as certain sections of the African elite and bureaucracy come to internalise the neo-liberal values of governance and even develop toolkits that will not be radically different from those usually developed in the think tanks of the West. An immediate example is the African Peer Review Mechanism (APRM) which was approved in Cape Town in July 2003, as a 'mutually agreed' and 'voluntary' instrument for self-monitoring 'to ensure that the policies and practices of participating states conform to the agreed political, economic and corporate governance values, codes and standards contained in the Declaration on Democracy, Political, Economic and Corporate Governance' (Abrahamsen 2004a: 1459). As Chabal (2002: 462) has informed us, 'NEPAD must ... be understood as a commitment on the part of the current (and not so new) elites in Africa to the present "democratic orthodoxy" in order to guarantee a transfer of resources to Africa: a continuation with, rather than a break from, the type of relations that has guided the continent's engagement with the international community since independence'.

\section{Alternative Futures and Challenges of Human Security in Airica}

The paper has demonstrated that the discourse on security in Africa has altered significantly in the last two decades; against the background of the termination of the Cold War and given the powerful contradictions deriving from the present global regime of globalisation. Regarding the global attention to human security as a new security focus for Africa, the paper showed that it is still a long way before the concept becomes a credible framework side-by-side with established notions of security based on regimes, state and territoriality. Another point is that the underlying assumptions of globalisation, and of NEPAD, based as they are on neoliberalism, cannot serve the cause of human security, even as it continues to undermine regime security, state security and territorial security. The final point is that given the pressing imperative for new security models for Africa, closer attention should be paid to those issues that portend grave and direct danger for African peoples rather than, say, to the state, regime or territory.

What then are the alternative futures for Africa regarding meeting the present challenges of human security? The first point to bear in mind 
in this regard is that threats to human security no longer derive solely from the military actions of states, even though this is deriving new significance in the context of global anti-terrorism as shown below. Arguably one of the most substantive problems facing Africa today has to do with the ebbing capacity of the state to mobilise and deliver public good in a manner that is as fair and equitable as possible to bring economic, political, environmental, health and cultural benefits to the people. In the future, then, new security issues concerning Africa would include rising poverty and rising incidents of conflict, rising migration and refugee flows, cross-border criminalities, increasing environmental stresses and strains, demographic pressures on resources, deterioration in human security provisions, the diffusion of military technological knowhow, skills and expertise of sub-state actors, proliferation of illegal arms, drug trafficking, money laundering, and international terrorism (Adekanye 2004: vi). Others would include the implications of growing social and economic exclusion and the general marginalisation of the people, political disenfranchisement, illicit human and drug trafficking, social insecurity, environmental degradation, unemployment, youth violence, epidemic and health issues, including the notorious HIV/AIDS pandemic, piracy, ethnic and religious conflicts; in short, issues that touch on the lives and day-to-day survival of peoples in different countries within the continent (Ostergard 2002: 333-350).

How African countries are able to cope with these myriad problems will determine whether or not the future will be bright or pale. Unfortunately, there is limited room for optimism even as individual countries demonstrate remarkable resilience in tackling the problems highlighted above. This brings to mind the African adage that if you cannot help me, then do not complicate my situation'. The import of this adage is best illustrated by one of the most formidable challenges deriving from the times that we live in: the implications of the global fight against terrorism initiated and led by the United States. In the aftermath of the terrorist attacks of September 2001, Washington promptly redefined its worldwide rule of engagements around antiterrorism; a development that has brought Africa - a continent with considerably more Muslim populations than the Middle East - into visibility on the global geo-strategic map of the United States which has recognised this large population as prone to radical Islam (Botha 2004: 3-10). Although individual governments at the sub-regional and regional levels may slowly latch on to the global anti-terrorism campaign, they 
would be doing so more through external prompting than any independent/ unilateral assessment of the dangers posed to them by terrorism. Even then, as they reluctantly join the global anti-terrorism movement, only intangible and imitative commitments are expected of them. ${ }^{9}$

Because Africa's counter-terrorism initiative will more likely be externally driven, it may be difficult to separate it from the individual interests of sponsoring powers. ${ }^{10}$ Addo (2004: 18) noted that '[The] challenging issue currently is whether efforts made so far have been effective or credible enough in preventing and combating terrorism, and if other equally relevant alternatives exist for dealing with terrorism in Africa given other developmental challenges faced by the continent'. The scenario that plays out therefore is one in which support for Africa will be conditional upon progress, as determined by the West, made to complement the global (read: United States) anti-terrorism campaign. Quite correctly, this type of demand on Africa by the West is nothing new. What is perhaps different is that it is assuming greater visibility and potent implications for human security on the continent as illustrated by the growing tendency by governments facing staunch oppositions to label them as terrorists and to use the language of anti-terrorism as a pretext for 'official' clampdowns and repression. In such countries, state repression and anti-terrorism becomes two sides of the same coin thriving on each other. As troubled governments become more repressive and authoritarian, they could count on support from the major sponsors of the global anti-terrorism movement simply by establishing some linkage, no matter how thin, between domestic opposition and one or the other pathologies of popular terrorist organisations. This tendency, in turn, would lead to a new and dangerous paradox: as African governments sign up to the global anti-terrorism project, the ordinary population may find themselves at even greater risk.

\section{Notes}

1. Revised version of paper presented at the 11 th CODESRIA General Assembly, Maputo, Mozambique, 6-10 December, 2005 on the theme: Rethinking African Development: Beyond Impasse, Towards Alternatives. The original version of the paper was written during residency as Visiting Leventis Cooperation Scholar to the Centre for African Studies, School of Oriental and African Studies, London, UK, from September to December 1995.

2. See www.globalpolicy.org/socecon/develop/africal.htm.

3. 'Editorial: Africa - Making Democracy Work', The Round Table, 93, 375, July 2004: 307-310. 
4. See also 'Outline of the Report of the Commission on Human Security', http://www.humansecurity-chs.org/finalreport/Outlines/outlines.pdf (accessed on November 16, 2005).

5. For details on the Protocol Relating to the Establishment o the Peace and Security Council of the African Union (AUPSC), Durban, South Africa, July 9, 2002, see Levitt, 2003: 161-186.

6. For details of the Draft Kampala Document for the Proposed Conference on Security, Stability, Development and Cooperation in Africa (CSSDCA) Kampala, Uganda, May 23, 2001, see Levitt, 2003: 227-248.

7. AHG/235 (XXXVIII) Annex 1: 2.

8. AHG/235 (XXXVIII) Annex 1: 1.

9. But then there is an OAU Convention on the Prevention and Elimination of Terrorism adopted in October 2002 at the Summit in Dakar, Senegal (Addo 2004: 11-19).

10. Several external efforts are currently in place: British Military Advisory and Training Team (BMATT), Reinforcement of African Peacekeeping Capabilities (RECAMP), African Contingency Operations Training Assistance (ACOTA), and the Global Rapid Deployment Force sponsored by the G-8 (Addo 2004: 18).

\section{Reierences}

Abdullahi, Ibrahim, ed., 2004, Between Democracy and Terror: The Sierra Leone Civil War, Dakar: CODESRIA.

Abrahamsen, Rita, 2004a, 'The Power of Partnerships in Global Governance', Third World Quarterly, 25, 8: 1453-1467.

Abrahamsen, Rita, 2004b, 'A Breeding Ground for Terrorists? Africa and Britain's "War on Terror"', Review of African Political Economy (ROAPE), 102: 677-684.

Adebajo, Adekeye, 2002, Building Peace in West Africa: Liberia, Sierra Leone and GuineaBissau, Boulder and London: Lynne Rienner Publishers.

Adebajo, Adekeye, 2004, 'From Congo to Congo: United Nations Peacekeeping in Africa after the Cold War', in Ian Taylor and Paul Williams, eds., Africa in International Politics: External Involvement on the Continent, London: Routledge: 195-212.

Adekanye, Bayo Adekson, 2004, 'Globalisation: An Introduction', Ibadan Journal of Social Sciences, 2, 1, September.

Adesina, J. O., 2005, Africa and Development Challenges in the New Millennium: The NEPAD Debate, London: Zed Books.

Addison, Tony, 2004, 'Introduction', in Tony Addison ed., From Conflict to Recovery in Africa, Oxford: OUP.

Addison, Tony, 2005, 'Conflict and Peace Building: Interactions between Politics and Economics', The Round Table; September, Vol. 94, No. 381: 405-411.

Addo, Prosper, 2004, 'The War on Terrorism and Africa's Peace and Security Agenda', Conflict Trends, 3/2004: 1 1-19.

African Research Bulletin, 2003, 'G7 to G8: Marketing NEPAD', African Research Bulletin, 39, 2, February 16 - March 15: 15099-15134. 
African Research Bulletin, 2004, 'African Union: Continental Parliament Inaugurated', African Research Bulletin, 41, 3, March 1-31: 15663-15698.

Ajayi, Ibi, 2004, 'Issues of Globalisation in Africa: The Opportunities and Challenges', Ibadan Journal of Social Sciences, 2, 1, September.

AJulu, Roy, 2004, 'African Security: Can Regional Organizations Plan a Role?', in Shannon Field, Peace in Africa: Towards A Collaborative Security Regime, Johannesburg, South Africa: Institute for Global Dialogue: 265-282.

Ake, Claude, 2000, The Feasibility of Democracy in Africa, Dakar: CODESRIA.

Akindes, Francis, 2004, 'The Roots of the Miitary-Political Crises in Côte d'Ivoire', Uppsala: Nordic Africa Institute Research Report no. 128.

Alusala, Nelson, 2004, 'DRC: On The Road to Disarmament', in Nelson Alusala and Thokozani Thusi, eds., A Step Towards Peace: Disarmament in Africa, Pretoria: ISS.

Ayoob, Mohammed, 1995, The Third World Security Predicament: State Making, Regional Conflict and the International System, Boulder: L. R. Publishers.

Bassey, Celestine O., 2003. 'The Nature and Character of Civil Wars in West Africa in the 1990s', in Amadu Sesay, ed., Civil Wars, Child Soldiers and PostConflict Peace Building in West Africa, Ibadan: College Press and Publishers Limited.

Bischoff, Paul-Henri, 2005, 'A Reflection on Peace Agreements in Africa', Conflict Trends, 1: 7-11.

Botha, Pierre, 2004, 'United States Counter-Terrorism Programmes in Africa: An Overview', Conflict Trends, 3: 3-10.

Boulden, Jane, ed., 2003, Dealing with Conflict in Africa: The United Nations and Regional Organisations, New York and Basingstoke: Palgrave Macmillan.

Boyd, Rosalind, 2005, 'Gender and Human Security Issues: Building a Programme of Action-Research', Development in Practice, 15, 1, February: 1 15-121.

Bracking, Sarah and Graham Harrison, 2003, 'Imperialism and New Forms of Accumulation', ROAPE, 95: 5-10.

Bush, Kenneth D. and Keyman, E. F., 1997, 'Identity-based Conflict: Rethinking Security in the Post-Cold War World', Global Governance, 3, 3: 31 1-328.

Cawthra, Gavin, 2004, 'A Conceptual Framework for Regional Security', in Shannon Field, ed., Peace in Africa: Towards A Collaborative Security Regime, Johannesburg, South Africa: Institute for Global Dialogue: 27-40.

Chabal, Patrick, 2002, 'The Quest for Good Government and Development in Africa: Is NEPAD the Answer?', International Affairs, 78, 3: 447-462.

Chandler, David, 2004, Constructing Global Civil Society: Morality and Power in International Relations, Basingstoke: Palgrave.

Clapham, Christopher, 1996, Africa and the International System: The Politics of State Survival', Cambridge: University Press.

Clover, Jenny, and Richard Cornwell, 2004, 'Supporting Sustainable Livelihoods: A Critical Review of Assistance in Post-Conflict Situations', Pretoria: ISS.

Colletta, Kostner and Ingo Wiederhofer(eds.), 1996, The Transition from War to Peace in Sub-Saharan Africa, Washington DC: The World Bank. 
Cooper, Neil and Michael Pugh, 2002, 'Security Sector Transformation in PostConflict Societies', The Conflict, Security and Development Group Working Paper, February.

Cooper, F., 2001, 'What is the Concept of Globalisation Good For? An African Historian's Perspective’, African Affairs, 100: 399.

Deegan, Heather, 2004, 'Global Agendas for Political Reform: The case of Africa', The Round Table, 93, 375, July: 355-368.

Diescho, Joseph, 2002, 'Understanding the New Partnership for Africa's Development', Windhoek: Namibia Institute for Democracy and KonradAdenauer-Stiftung.

Farah, D., 2002, 'Terror Thrives in the Rich Runs of Africa', Washington Post, January.

Fawole, Alade W., 2004, 'A Continent in Crisis: Internal Conflicts and External Intervention in Africa', African Affairs, 103: 297-303.

Fayemi, Kayode and Dylan Hendickson, 2002, 'NEPAD: The Security Dimension (Briefing)',. Democracy and Development - Journal of West African Affairs, 17, 1: $67-68$.

Federici, Silvia and George Caffentzis, 2004, 'Globalisation and Professionalisation in Africa', Social Text 79, 22 (2): 81-100.

Federici, Sylvia, 2000, 'War, Globalisation and Reproduction', Peace and Change, 25, 2: 153-165.

Forge, John W., 2004, 'Facing the Challenges of Globalisation', African Identities, 2, 1: 7-35.

French, Howard W., 2004, A Continent for the Taking: The Tragedy and Hope of Africa, New York: Alfred A. Knopf.

Gberie, Lansana, 2005, 'Africa: The Troubled Continent', African Affairs, 104, 415 : 337-342, [Review Article].

Graham, David T. and Nana K. Poku, eds., 2000, Migration, Globalisation and Human Security, London: Routledge.

Griggs, Richard A., 2003, 'Geopolitical Discourse, Global Actors and the Spatial Construction of the African Union', Geopolitics, 8, 2, Summer: 69-98.

Hammerstad, Anne, 2004, Africa's Commitments to Democracy in Theory and Practice: A Review of Eight NEPAD Countries', African Human Security Initiative.

Harris, Geoff, 2004, 'The Case for Demilitarization in sub-Saharan Africa', in Geoff Harris ed., Achieving Security in sub-Saharan Africa: Cost Effective Alternatives to the Military, Pretoria: ISS: 1-15.

Held, David, 1997, Democracy and Globalisation. Global Governance, 3 , 3 : 25 1267.

Herbst, Jeffrey, and Greg Mills, 2003, 'The Future of Africa: A New Order in Sight?', Adelphi Paper 361, Oxford: OUP.

Herbst, Ross, 2004, 'The Survival of NEPAD and the APRM: A Critical Analysis', South Africa Journal of International Affairs, 11 1:21-38.

Hope, Kempe Ronald Sr., 2002, From Crisis to Renewal: Towards a Successful Implementation of the New Partnership for Africa's Development', African Affairs, 101: 387-402.

Hoppers, Catherine O., 2000, Cited in Editorial, Peace and Change, 25, 2, April. 
Hughes, Christopher W., 2002, 'Reflections on Globalisation, Security and 9/1 1', Cambridge Review of International Affairs, 15,3.

Ihonvbere, Julius O., 2000, Africa and the New World Order, New York: Peter Lang. Ilorah, Richard, 2004, 'NEPAD: The Need and Obstacles', African Development Bank: 223-251.

International Crisis Group (ICG), 2004, Liberia and Sierra Leone: Rebuilding Failed States, ICG Africa Report No. 87: Dakar/Brussels.

Jackson, Richard, 2000, 'Managing Africa's Violent Conflicts', Peace and Change, 25: 208-224.

Jaye, Thomas, 2003, 'Liberia, An Analysis of Post-Taylor Politics', ROAPE, 98 : 643-686.

Jaye, Thomas, 2005, 'Understanding the Conflict in Côte d'Ivoire', Conflict Trends, $1: 27-31$.

Jinadu, L. Adele, 2000, 'The Dialectics of Democracy, Development, Peace and Security in Africa', in L. Adele Jinadu, ed., The Political Economy of Peace and Security in Africa: Ethnocultural and Economic Perspectives, Harare, Zimbabwe: AAPS Books: 1-11.

Juhasz, Antonia, 2002, 'The Failure of Globalisation', Cambridge Review of International Affairs, 15, 3.

Kanbur, Ravi, 2002, 'The New Partnership for Africa's Development (NEPAD): An Initial Commentary', Politikon, 29, 1: 87-100.

Keenan, J., 2004, 'Terror in the Sahara: The Implications of US Imperialism for North and West Africa', Review of African Political Economy, 31, 101: 475-496.

Kruse, Keith and Michael C. Williams, 1996, 'Broadening the Agenda of Security Studies: Politics and Methods', Mershon International Studies Review, 40, 2, October: 229-254.

Lawson, L., 2003, 'Globalisation and African States', Commonwealth and Comparative Politics, 41, 3: 37-58.

Levitt, Jeremy I., ed., Africa: Selected Documents on Constitutive, Conflict and Security, Humanitarian and Judicial Issues, New York: Transnational Publishers, Inc.

Lyman, P. N. and Morrison, J. S., 2004, 'The Terrorist Threat in Africa', Foreign Affairs, 83: 75-86.

Malcomson, Dave, 2004, 'Overview of the Implementation of NEPAD Initiative', South African Journal of International Affairs, , 11 1: 1 1-20.

Mandel, Robert, 1994, The Changing Face of National Security: A Conceptual Analysis, Westport, Connecticut: Greenwood Press.

Manning, Carrie, 2002, 'The Politics of Peace in Mozambique: Post-Conflict Democratisation (1992-2000)', Westport, CT and London: Praeger.

Mathews, K., 2001, 'Birth of the African Union (AU)', Africa Quarterly. 41 (1-2), January-June, 113-120.

Mathews, K., 2003, 'The African Union: From Dream to Reality Focus on the Maputo Summit', Africa Quarterly, 43, 2: 1-16.

Matthews, Sally, 2004, 'Investigating NEPAD's Development Assumptions', ROAPE, 101: 497-511.

Mbaku, John Mukum, 2004, 'NEPAD and the Prospects for Development in Africa', International Studies, 41, 4: 387-409. 
Meagher, Kate, 2003, 'A Backdoor to Globalisation? Structural Adjustment, Globalisation and Transborder Trade in West Africa', ROAPE, 95: 57-75.

Melber, Henning, 2002, 'The New Partnership for Africa's Development (NEPAD) - Old Wine in New Bottles?', Forum for Development Studies, 1: 186-209.

Melber, Henning, Richard Cornwell, Jephthah Gathaka and Smokin Wanjala, 2002, 'The New Partnership for Africa's Development (NEPAD), African Perspectives', Uppsala: NAI Discussion Paper 16.

Mentan, Tetah, 2004, Dilemmas of Weak States: Africa and Transnational Terrorism in the Twenty-First Century, Aldershot and Burlington, VT: Ashgate.

Mepham, David and James Lorge, 2005, 'Putting Our House in Order: Recasting G8 Policy Towards Africa', London: Institute for Public Policy Research (IPPR).

Mills, Greg, 2004, 'Africa's New Strategic Significance', Washington Quarterly, 27, 4: $157-164$.

Morton, Adam David, 2004, 'New Follies on the State of Globalisation Debate?', Review of International Studies, 30: 133-147.

NEPAD, 2005, African Post-Conflict Reconstruction Policy Framework. Pretoria: NEPAD Secretariat, June.

'NEPAD: Peer Review Mechanism', 2002, African Research Bulletin, 39, 10, October 16-Novemenber 15, 2002: 15398-15399.

Niekerk, Anthoni van, 2004, 'The Role of the AU and NEPAD in Africa's New Security Regime', in Shannon Field, ed., Peace in Africa: Towards A Collaborative Security Regime. Johannesburg, South Africa: Institute for Global Dialogue: 41-62.

Nnoli, Okwudiba, 2003, 'Globalisation and African Political Science', African Journal of Political Science, 8, 2: 11-32.

Oberleitner, Gerd, 2005, 'Human Security: A Challenge to International Law?', Global Governance, 1 1: 185-203.

Obono, Oka, 2004, 'Globalisation and Multiculturalism in Sociology: An Essay on Contradictions', Ibadan Journal of Social Sciences, 2, 1, September: 87105.

Olsen, Gorm Rye, 2004, 'Challenges to Traditional Policy Options, Opportunities for New Choices: The African Policy of the EU', The Round Table, 93, 375, July: 425-436.

Olsen, G. R., 2002, 'Promoting Democracy, Preventing Conflict: The European Union and Africa', International Politics, 39, 3, September: 311-328.

Olsen, Gorm Rye, 1998, 'Europe and the Promotion of Democracy in Post Cold War Africa: How Serious is Europe and for what Reason', African Affairs, 97: 343-367.

Olukoshi, Adebayo, 2003, 'Governing the African Development Process: The Challenge of the New Partnership for Africa's Development', in Holger Brent Hansen and Maj-Britt Johannsen, eds., The Challenge of the New Partnership for Africa's Development, Copenhagen: University of Copenhagen North/South Priority Research Area: 11-44. 
Olukoshi, Adebayo, 2003, Globalisation, Equity and Development: Some Reflections on the African Experience, Dakar: CODESRIA.

Ostergard, Robert L. Jr., 2002, 'Politics in the Hot Zone: AIDS and National Security in Africa', Third World Quarterly, 23, 2: 333-350.

Packer, Corinne A.A. and Donald Rukare, 2002, 'The New African Union and its Constitutive Act', The American Journal of International Law, 96, 2: 365-379.

Pettman, Ralph, 2005, 'Human Security as Global Security: Reconceptualising Strategic Studies', Cambridge Review of International Affairs, 18, 1: 137-150.

Richard, Paul, ed., 2005, No Peace No War: An Anthropology of Contemporary Armed Conflicts, Athen, Ohio: OUP and Oxford: James Currey.

Richards, Joseph, 2003, 'Governance and Insecurity in Africa', Democracy and Development - Journal of West African Affairs, 3, 2: 7-16.

Richards, Joseph, 2003, 'Africa: States in Crisis', Journal of Democracy, 14, 3: 159 170.

Sabelo, J. Ndlovu-Gatsheni, 2004, 'Putting People First - From Regime Security to Human Security: A Quest for Social Peace in Zimbabwe, 1980-2002', in Alfred G. Nhema, ed., The Quest for Peace in Africa: Transformations, Democracy and Public Policy, Addis Ababa: International Books with OSSREA: 297-322.

Swyngedouw, Erik, 2004, 'Globalisation or "Glocalisation"? Networks, Territories and Rescaling', Cambridge Review of International Affairs, 17, 1.

Taisier, Ali, M. and Matthew, Robert O., 2004, Durable Peace: Challenges for Peacebuilding in Africa, Toronto, Buffalo, London: University of Toronto Press.

Taylor, Ian, and Paul Williams, 2004, 'Introduction: Understanding Africa's Place in World Politics', in Ian Taylor and Paul Williams, eds., Africa in International Politics: External Involvement on the Continent, London: Routledge: 1-22.

The Round Table, 'Editorial: Africa - Making Democracy Work', The Round Table, 93, 375, July: 307-310.

Thomas, Caroline, and Peter Wilkin, eds., 1999, Globalisation, Human Security and the African Experience, Boulder, CO.: Lynne Rienner.

Thompson, Carol B., 2004, 'US Trade with Africa: African Growth and Opportunity?', ROAPE, 101: 457-474.

Tieku, Thomas Kwasi, 2004, 'Explaining the Clash and Accommodation of Interests of Major Actors in the Creation of the African Union', African Affairs, 103: 249-267.

Vasu, Gounden, 2005, 'Conditions for Peace: The State, Private Security and Civil Society’, Conflict Trends, January: 12-14.

Vavrynen, Raimo, 1995, 'Concept of Security Revisited', Mershon International Studies Review, 39, 2, October: 259-262.

Waal, Alex de, 2002, 'What's New in the 'New Partnership for Africa's Development?', International Affairs, 78 (3) July: 463-476.

Willet, Susan, 2004, 'Development and Security in Africa: A Challenge for the New Millennium', in Geoff Harris, ed., Achieving Security in Sub-Saharan Africa: Cost Effective Alternatives to the Military, Pretoria: ISS: 101-120. 